\title{
Helen Suzman: The Hour Brings Forth the Woman
}

\section{John Nieuwenhuysen ${ }^{1}$}

In the annals of parliamentarianism in the English-speaking world, Helen

Suzman may have been the best there ever was.

The Times

Helen Suzman, who died in January this year, aged 91, was a courageous, fearless and persistent critic of South Africa's apartheid regime. Her brilliant and biting attacks were based on thorough research and analysis, and driven by her passion for human rights and justice. As a Member of Parliament for 36 years, from 1953-89, she laid bare the discrimination, brutality and ineptitude of apartheid. Helen's speeches were a light to the world, an inspiration to many of her fellow South Africans, and a thorn in the flank of the ruling Afrikaner Nationalist Party.

Born Helen Gavronsky in 1917, she was the daughter of financially successful Lithuanian Jewish migrants who came to South Africa at the turn of the century. But her early days in Johannesburg did not presage subsequent worldwide renown. After matriculating aged 16, she attended the University of Witwatersrand as a commerce student and found life 'carefree and enjoyable'. She dropped out of university, aged 19, in 1937, and married Dr Mosie Suzman, returning in 1939, after the birth of their first child, to complete her degree. In this, she obtained distinctions in Economic History and (African) Law and Administration.

Helen's war years were spent with the Supplies Board, which tracked down war profiteers, a job she found 'boring but essential'. In 1945, at the invitation of the illustrious Professor Herbert Frankel, Helen was appointed tutor and subsequently lecturer in Economic History at the University of the Witwatersrand. In her 1993 memoirs, In No Uncertain Terms, she observed: 'Those years of teaching the economic history of South Africa were to prove enormously useful to me when I became an MP, for they provided a solid background on which to base my speeches and develop my skills in researching source material.' (p.12)

It was also during the eight years at the University that Helen joined the Institute of Race Relations and gained a detailed knowledge of the discrimination

\footnotetext{
1 The Institute for Global Movements, Monash University, john.nieuwenhuysen@education.monash.edu.au.
} 
against non-whites, especially in the labour market and in civil liberties. She observes in her memoirs that 'before and during the Second World War, I was much more concerned about the defeat of Nazism than about the disabilities of Black South Africans. Thus I was a late starter in the field of race relations, but once I got going, I became entirely preoccupied with it.' (p.13)

After being elected to Parliament in 1953 as a member of the United Party, Suzman with nine of her colleagues formed the Progressive Party in 1959. In the 1961 election, she was the only one of the 10 to survive. Helen was thus for the 13 years from 1961-74 the only Progressive in the House. Her loneliness was accentuated for six of these years during which she was the only woman among 165 male, largely very chauvinistic, MPs. As Stanley Uys noted, Helen's complete fearlessness showed as she was 'confronted ... by some of the most menacing and odious politicians of any parliament ever.' 2

It is hard, I suspect, for those accustomed to a democratic society with a free press and the rule of law to envisage the stifling and confining effect of a controlling, police-state regime, such as apartheid, on its citizens. The special edge of this for white opponents of apartheid like Helen was to be dubbed a traitor and subjected to maligning treatment, including hate mail and abusive phone calls (in response to which Helen would vigorously blow a police whistle down the line).

Ironically, onslaught on Helen's views came not only from Government ranks in Parliament (who shouted 'go back to Israel/Moscow') and other apartheid supporters, but also from some in the freedom struggle, who accused her of supping with the devil and of racism. I personally witnessed young students in Melbourne chanting 'racist, racist' at Helen when she addressed a meeting here in the 1970s. (Characteristically she refused to be silenced.)

How did such divided responses to Helen Suzman arise? Liberation movement critics alleged that she condoned apartheid by participating in the white Parliament; and they were incensed when (with British PM, Margaret Thatcher) Helen opposed economic sanctions against South Africa.

It is hard to judge the merits of the sanctions debate. But there is no doubt that Helen's parliamentary role made a remarkable contribution in publicising the evils of apartheid. Her powerful evidence-based oratory and cross-questioning spread the knowledge of how rotten was the state of apartheid South Africa. Despite being in a minority of one, Helen's invective against apartheid's leaders could hit marks with unforgettable force. She once told the Minister of Justice that he should visit his constituency 'heavily disguised as a human being', and referred to the head of State Security as 'South Africa's very own Heinrich Himmler'. She dismissed the government as 'narrow-minded, prejudiced bullies'.

2 The Guardian, 9 January 2009. 
In addition to her exceptional forensic skills in the House, Helen was a tireless grassroots operator who sought personally to help as many people as possible, particularly the vulnerable and voteless. She would take up individual cases with the administration, and was able as an MP to regularly visit those in the resistance struggle who had been imprisoned. Helen developed in this way a strong and lasting friendship with Nelson Mandela and many of his colleagues, including Mosiuoa Lekota, the leader of the recent ANC breakaway Party, Congress of the People (COPE). As to whether this made a difference to the lives of the freedom fighters, Professor David Welsh's tribute to Helen recounts an episode when, with her, in 1989, he visited Zambia to meet ANC people: 'A young militant accosted her, saying that serving as an MP legitimised an unjust system. Helen ... turned to Steve Tshwete, a former Robben Islander, and subsequently a Cabinet Minister, and asked him whether she had made a difference. Tshwete simply put his arms around Helen and hugged her.' ${ }^{3}$

However, Helen was fiercely independent, and did not resile from criticising the ANC when she felt that there were excesses in the liberation struggle or, after freedom, in ANC-controlled government policy. This meant unpopularity for her in some circles, both in the way in which ANC leaders disparaged the role of the Progressives in the anti-apartheid struggle, and in their resentment of her policy criticisms once they gained power.

Helen's Herculean public labours did not, however, prevent her from enjoying life to the full. She was a gregarious, warm, fun-loving person, strongly attached to family and a wide circle of friends, and possessed of a great sense of humour. (David Welsh tells of an occasion over lunch with Helen and foreign diplomats in the South African Parliament dining room when, served a dubious looking fruit juice, she raised her glass to the light and said: 'Cloudy today, Doctor.')

My own limited contact with Helen Suzman leaves a memory of a kind, caring, inspiring and generous person. Prior to her visit to Australia in the 1970s, Helen had met my father in Pretoria and offered to contact me in Melbourne. Despite a busy schedule, she did so and, on her return, wrote a lovely letter to my Dad, summing up my condition precisely in Afrikaans: 'Ek dink hy verlang na sy vaderland' - I think he longs for his fatherland, which was exactly so.

In 1994, after the first free elections in South Africa, I heard that Helen was to visit Australia. As Director of the Bureau of Immigration, Multicultural and Population Research, I invited her to address a meeting in Melbourne and she accepted. Held at Mietta's wonderful premises, and filled to the rafters, Helen was greeted as the hero she was. Sir Zelman Cowen, a former Governor General, chaired the occasion, and Sam Lipski, then editor of the Jewish News, and Dr Jay Sadhai of the South African Cultural Association, spoke eloquently in

3 Cape Times, 10 January 2009. 
welcome. Helen's own speech lasted 50 minutes, and was brilliantly delivered, without a note. She held the audience in the palm of her hand, and along with the new South African anthem, Nkosi Sikelela Afrika, it sent tingles down the spine.

There is an old saying that the hour brings forth the person. In South Africa's hard road to democracy, several great people rose to the occasion, including four Nobel Prize Winners - Luthuli, Mandela, Tutu and de Klerk. Helen Suzman was twice (unsuccessfully) nominated for the Nobel Prize, so obviously at least some close to the throne believed she deserved one. Nonetheless, she received a remarkable list of honours, including Dame of the British Empire (though under Britain's quaint rules, non-British citizens are not able by custom to use the title, as in 'Dame Helen Suzman'). Even more impressive were the 26 prestigious honorary university doctorates which she was awarded. The bravery and isolation of her struggle in the South African Parliament and society against apartheid deserved these accolades.

Helen Suzman was an inspirational leader who believed that right must be done, and laboured tenaciously with all her heart and soul to try and make it so. 